Article Type: Persuasive Paper

\title{
Public Accounting and Business Accounting: Two Different Upstream
}

\author{
Irwan Taufiq Ritonga ${ }^{1 *}$
}

\section{글}

\section{AFFILIATION:}

${ }^{1}$ Department of Accounting, Universitas Gadjah Mada, Yogyakarta, Indonesia.

\section{*CORRESPONDENCE: \\ irwanritonga@ugm.ac.id}

THIS ARTICLE IS AVAILABLE IN:

http://journal.umy.ac.id/index.php/ai

DOI: 10.18196/jai.2103156

\section{CITATION:}

Ritonga, I. T. (2020). Public Accounting and Business Accounting: Two Different Upstream. Journal of Accounting and Investment, 21(3), 401-416.

\section{ARTICLE HISTORY}

\section{Received:}

16 June 2020

Reviewed:

25 June 2020

Revised:

1 July 2020

Accepted:

15 Aug 2020

\begin{abstract}
:
Research aims: This article is a persuasive essay, written with motivation to change readers' perceptions of accounting for public organizations, especially government organizations. This article aims to provide arguments following detailed explanations that accounting of public organization and accounting of business organization stand on two different accounting-world.

Design/Methodology/Approach: This article is a persuasive essay.

Research findings: The differences between the two have started since the beginning of the formation of each organization, namely differences in motives and backgrounds of the formation of the organization, goals of the organization's establishment and how to achieve organizational goals, as well as the source and nature of organizational funding.

Theoretical contribution/ Originality: These differences in the upstream give consequences differences in downstream, which are significant dissimilarities between the two accounting worlds on planning and budgeting aspects, financial reporting systems (financial accounting), managerial accounting, and auditing. Practitioner/Policy implication: This significant difference in accounting education implies that the curriculum of accounting education must be reconsidered by separating the public accounting curriculum and the business accounting curriculum.
\end{abstract}

Keywords: Public Accounting; Governmental Accounting; Business Accounting

\section{Introduction}

To the time of this writing, accounting that focused on a not-for-profit organization is named Public Sector Accounting. The word "sector" that put in that name places accounting for the not-for-profit oriented organization as if it is a subordinate or a branch of "a big" accounting, in this case accounting for business organizations. This fact is reflected in the curricula of the department of accounting/school of accounting all around the world, where the number of courses that cover accounting for a notfor-profit organization is very limited in number. For example, in the Accounting Department of the Faculty of Economics and Business Universitas Gadjah Mada, students only get two compulsory courses related to public accounting (FEB UGM, 2020). Most of the mandatory courses that must be taken by students are accounting courses for a business organization. As a consequence of this bias, accounting students have insufficient knowledge and competence in public accounting. 


\section{Ritonga}

Public Accounting and Business Accounting: Two Different Upstream

To author's experience when asking senior accounting students why government entities implement budgetary accounting while it does not exist in business entities, most students cannot explain well. In turn, when they graduate from university, they are not ready to work in public organizations, such as central and local government offices, the supreme audit board offices, etc. For example, they do not understand how to journal budget realization transactions and do not adequately understand government financial statement accounts. As a result, the government must incur additional costs to educate and train them.

On the other side, in terms of "market size", public organizations are as big as business organizations. Using Indonesia pictures, Table 1 below shows the comparison between the market size of business organizations and public organizations. In this case, public organizations ${ }^{1}$ are represented by government entities because government organization is a public organization that has been established in terms of accounting infrastructure, regulation, complete, reliable database, and has a significant economic impact on the national economy.

Table 1 Comparison of Market Size between Business Organization and Public Organization

\begin{tabular}{llll}
\hline No & Aspects & \multicolumn{1}{c}{ Government Organizations } & \multicolumn{1}{c}{ Business Organizations } \\
\hline 1. & $\begin{array}{l}\text { Large Scale } \\
\text { Entity }\end{array}$ & $\begin{array}{l}\text { 608 entities consist of 60 entities of } \\
\text { central government (33 ministries, 27 } \\
\text { state institutions) (Kementerian } \\
\text { Komunikasi dan Informatika, 2020), } 548 \\
\text { entities of local government (34 } \\
\text { provinces, 416 regencies, 98 cities) } \\
\text { (Kompas, 2020) }\end{array}$ & $\begin{array}{l}\text { Indonesia Stock Exchange } \\
\text { (BEI, 2020) }\end{array}$ \\
& $\begin{array}{l}74,953 \text { Village Government (Republik } \\
\text { Indonesia, 2019b) }\end{array}$ & $\begin{array}{l}\text { 60,702 medium business } \\
\text { units (Kementerian } \\
\text { Kiddle Scale }\end{array}$ \\
& & $\begin{array}{l}\text { Komunikasi dan Informatika, } \\
\text { 2020) }\end{array}$ \\
\hline
\end{tabular}

From Table 1, it can be seen that of the large-scale entities, there were more business entities than government entities. However, the "losing" of the number of government entities on a large scale was compensated by the higher number of village government entities than business entities in the medium-scale group. This fact indicates that the world of public accounting is no less broad compared to business accounting.

The size of the world of government accounting can also be reflected in the amount of labor needed. In the central government environment, there were around 21,700 working units (KSAP, 2008), which means it required 21,700 accounting personnel. This amount did not include the need for accounting personnel for supervisory functions at The Financial and Development Supervisory Agency and every inspectorate general of

\footnotetext{
${ }^{1}$ Public organizations refer to every organization that the main objective is to serve the public for not-forprofit orientation. Public organizations include governments, houses of worship (mosque, church, etc.), foundations, political parties, and so on.
} 
ministries/agencies; also, in the Audit Board as a function of state financial audit. In the local government, assuming that each local government consists of 53 working units, there is approximately 29,000 accounting staff (548 local governments x 53 working units). Besides, there are also two working units, The Inspectorate and The Financial Management Agency, which must be filled by accounting personnel. If the two working units each need ten accounting staff, it takes around 10,960 people (548 local governments $\times 10$ persons $\times 2$ working units). For the village government, assuming one accountant for one village, at least 74,953 people are needed.

If added together, then for government organizations alone, there are at least 136,600 more positions for accounting staff. If it is assumed that every year there are $5 \%$ of accounting staff who retire, die, or other causes, every year, there will always be needed at least around 6,850 new accounting personnel. This number is undoubtedly a vast number that must be supplied by universities. A large amount of accounting personnel required, as described above, provides compelling evidence that the world of public accounting is vast.

Why do not accounting for business organizations named as Business Sector Accounting? The author suspects that most academics believe that Business Accounting is the "parent" of all accounting "children," then the word "sector" would unnecessary. It is indeed undeniable because Business Accounting more rapidly develops than accounting for other organizations. As a result, if there is accounting for another organization growing and developing, it is called the accounting sector of the developing organization. For example, in Indonesia, reformations in local government with the implementation of regional autonomy resulted in the emergence of the need for accounting as a tool to account for local government financial management for more accountable and transparent. The growth and development of accounting in this government organization then gave rise to the term of Public Sector Accounting. In Indonesia, because government organizations dominate not-for-profit oriented organizations, the term Public Sector Accounting becomes identical with the term of Governmental (Sector) Accounting.

Again, the use of the word "sector" in Public Sector Accounting or Governmental Sector Accounting understate accounting for this organization. This phenomenon signifies as if public accounting is a branch of a larger "world" of accounting. The author argues that the most appropriate term should be Public Accounting rather than Public Sector Accounting by removing the word sector. Public Accounting is accounting, which has its own upstream that is different from Business Accounting. The author would present the arguments in the following section to support the above statements. In developing an explanation, the author used government entities in the context of Indonesia to represent the public organization. It is because government entities are the most wellorganized public entities and have the most significant influence on the national economy. Therefore, the author would employ the term public entities or government entities interchangeably. The arguments presented in this paper can be used as a reference in future studies, among others, in terms of explanations in constructing hypotheses, explaining phenomena that occur in public organizations, and so forth. 
The structure of this article is illustrated in the following figure. The structure also shows the thought framework in developing argumentation.

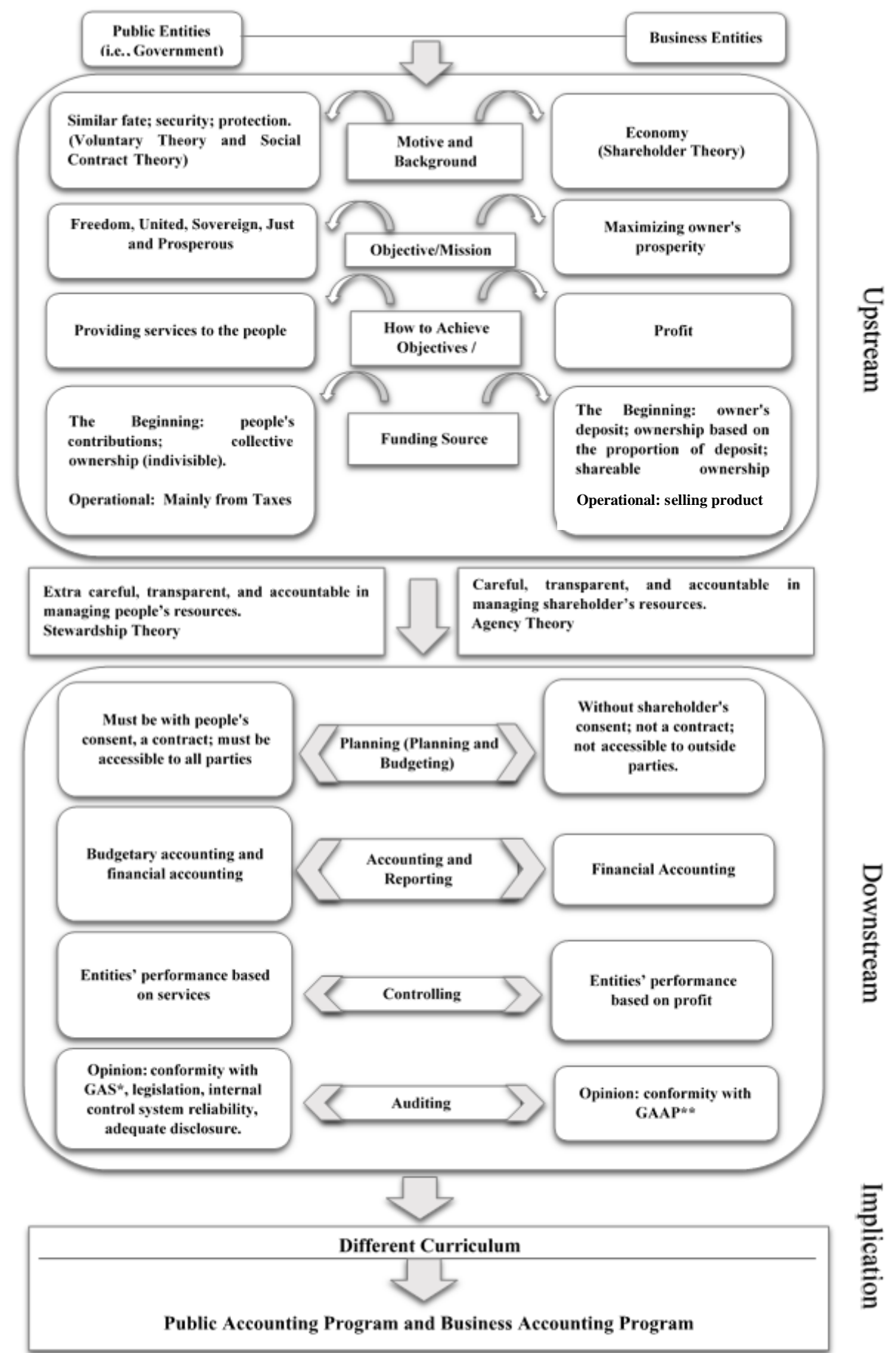

Figure 1 Thought Framework of Contrasting Public Accounting and Business Accounting *GAS= Governmental Accounting Standards **GAAP $=$ Generally Accepted Accounting Principles 
Ritonga

Public Accounting and Business Accounting: Two Different Upstream

\section{Public Accounting and Business Accounting: Two Different Upstream}

What meant by upstream here include motive and background of entities establishment, the purpose of entities establishment and how to achieve it, and entities' source of funding and ownership.

\section{Motive and Background of Entities Establishment}

Motive and Background of State Establishment

Several theories suggest the motivation of a state establishment. Among these theories are Voluntary Theory and Social Contract Theory. Voluntary Theory states that groups of communities establish a country because of rational common interests (Carneiro, 1970). Communities establish a group in the form of a state based on common interests. These interests could be aimed to gain prosperity, fight colonialism, or glory actualization. Meanwhile, the Social Contract Theory states that a state could be established through an agreement among community groups that have agreed to establish an organization that protects and guarantees the community's survival. This theory is embraced by Thomas Hobbes, John Locke, J.J. Rousseau, and Montesquieu.

In Indonesia's context, the process of establishment of The Unitary State of the Republic of Indonesia is closely related to the long history of struggles of the nations that inhabit the archipelago. The long history began from the Sriwijaya Kingdom, the Majapahit Kingdom, to Youth Pledge in 1928. Based on similarities on historical background and the feeling of being in the same boat, the founders of the Republic of Indonesia put common ideology into the Pancasila ${ }^{2}$ and 1945 Constitution of the Republic of Indonesia. In the form of The Republic of Indonesia, entire components of Indonesian people voluntarily unite themselves with rules and consequences as part of a state. The consequences include managing economic resources in the whole Indonesia region. Indonesian people see themself as a single entity; therefore, all potentially available resources, including economic resources, human resources, and natural resources enclosed in Indonesia territory, are used together to achieve common goals as a country.

Turning back, reviewing the history of the formation of Indonesia State, where leaders from all corners of the archipelago of Indonesia voluntarily gathered together and shared the same ideology to achieve Indonesia independence, the condition can be attributed to Voluntary Theory proposed by Carneiro (1970). Individuals who have similar backgrounds, spontaneously, rationally, and voluntarily surrender their sovereignty and unite with others to form a political unit called country. This theory had corresponded to Indonesia's conditions when it was established, where good figures from young and old fighters worked together to form a country and proclaimed Indonesian independence. They voluntarily appointed Soekarno as President of Indonesia. Furthermore, the Voluntary Theory is supported by the Social Contract

\footnotetext{
${ }^{2}$ Pancasila is the official and fundamental philosophical theory of the Indonesia State
} 
Theory, which sees someone, or political obligations morality depend on contracts or agreements between them to establish an organization. According to the arguments above, it can be concluded that the main motive to establish a state is non-economic.

Motives and Background of Company Establishment

A business organization is an organizational entity involved in providing goods or services to consumers (Sullivan and Sheffrin, 2003). This business entity is an economic unit formed by parties or individuals who share a common goal to get economic benefits from its business activities. The primary purpose of an individual establishing a company is to seek profits. Therefore, the main motive of company establishment is economical. As a result, each party in the entity has a different portion of ownership depends on their capital contribution. The higher the contribution submitted, the higher the proportion of ownership.

Comparison of Motives and Background of Establishment between States and Companies

States are formed based on the willingness of individuals to share strengths, weaknesses, opportunities, and threats. In the state's concept, all members (people) have the same rights and obligations, not depend on the individual/group's contribution to the country. The same condition also applies to legal and administrative aspects. In a broader context, every region in the state is required to give economic and noneconomic contributions to the country. The country does not provide certain privileges to a region based on the size of the region's contribution.

Business entities are established based on economic motives. Every party involved in the business entity is valued and positioned according to the size of their contribution. Roles, functions, responsibilities, and opportunities to obtain economic benefits and the obligation to bear the risk/loss depends on the size of contribution from each party involved in the business entity.

The significant difference in the motives and process of forming the state and company will affect the governance of these two entities in looking at the relationship between the entity and the owner.

\section{Purpose of Entities Establishment and Methods to Achieve the Purpose}

The Purpose of State Establishment and the Method to Achieve it

Universally, state establishment aims to achieve prosperity for its people. The Unitary State of Republic of Indonesia's purposes are stated in the Preamble of the 1945 Constitution in the second paragraph, which reads (the Republic of Indonesia, 1945):

"... Deliver Indonesian people to the front gate of Indonesia's independence, which is independent, united, sovereign, fair, and prosperous. " 
To achieve these aims, the state (i.e., all levels of government) must provide goods and services to the people. In the fourth paragraph of the 1945 Constitution Preamble, the mandatory services must be provided by the government to the people. These services protecting the entire nation and homeland of Indonesia, advancing the public welfare, educating the nation's life, and participating in the world order.

Based on the description above, it can be stated that a state establishment aims to create a just and prosperous society. To succeed in these aims, the government has to provide the best goods and services to its people in every aspect of life.

Purpose of Company Establishment and Methods to Achieve the Purpose

In general, a company is founded by a group of individuals who have the same aim, which is increasing their prosperity. The aim of increasing prosperity is achieved through profit on several capitals that have been submitted on company establishment. Although some business companies also engage in social aspects, the primary and longterm goals of the business are to get the maximum profit to provide economic benefits to business owners; or to minimize losses suffered by the owner when negative conditions happen to the business company.

Shareholder Theory states that the company's primary goal is to maximize shareholder value. Shareholder value refers to the value of equity, which presents the value of the benefits (i.e., cash flow) that shareholders can expect from the company. This theory can be associated with the company's goal of maximizing sales volume, profit, shareholder value, or market share.

Comparison of the Entity's Objective and the Way to Achieve the Purpose between State and Company

In general, public and business entities have a similar objective: to improve the welfare of the owner. However, the ways taken by the two entities are different. Business entities increase the owner's welfare by maximizing profits. Therefore, business entities referred to as profit orientation entities. On the other hand, to achieve its objectives, public entities (i.e., government) give the best goods and services to its people. Therefore, public entities referred to as not-for-profit organizations. In turn, employees who work in public/government agencies are labeled public servants/society servants. Different ways of achieving their objectives between business and public entities will affect the governance of two entities. For example, the performance measurement of government leaders will be different from a business leader. The performance of government leaders will be measured based on the ability to provide services to the people, while company leaders will be measured based on the ability to generate profits. 


\section{Entities Source of Funding and Ownership}

\section{Public Entity Source of Funding and Ownership}

At its initial establishment, the country needs "initial capital." This initial capital certainly comes from entire people's contributions, who stated to join the state. These contributions can be in the form of funds, human resources, natural resources, and others. The amount of contribution is not related to the ownership portion of the state. A region with abundant natural resources does not mean that it has a more significant portion of authority/ownership than other regions. For example, in the Indonesian context, at the beginning of its establishment, King Sultan Hamengkubuwono IX donated all Kraton Yogyakarta Kingdom gold reserves to the Republic of Indonesia to fulfill the requirements as a state for issuing its currency (Tempo, 2015). The abundant contributions from the King Sultan Hamengkubuwono IX do not make Province of Yogyakarta or the people of Yogyakarta have higher authority than people in other regions in Indonesia The state sees all people as the owners of the country with the same rights and obligations. This condition occurs because of the willingness to establish a country is based on ideological similarities, a similar sense of struggle, and a similar background.

In order to prosper its people, the government must provide services to its people. Every good and service provided by the government certainly requires funding sources. The question is, where does the central/local government get its funding sources? Of course, the answer is from the people and resources owned by the country (which, of course, belongs to the people). This is a consequence of a consequence of the spirit that underlies the country's founding, namely the feeling of being in the same boat among all people.

Besides, once a country is established, it needs sources of income to provide goods and services - such as health services, education, infrastructure, order, etc. - to the people. Jones and Pendleburry (2000) explained that a government could obtain income from people in two main ways, namely tax and retribution (charges). Both methods of obtaining public funds are not mutually exclusive. Therefore, it can be done in a combination (mixed) as well.

From all funding sources owned by the government, sources of operational funding from taxes are the dominant country's revenue. In the Indonesia context, the most significant and dominant government revenue for years comes from taxes. The tax contribution to total revenue in the state budget was 82,51\% in 2019 (Republik Indonesia, 2018), and 83,54\% in 2020 (Republik Indonesia, 2020). In around the world, the average tax contribution to total revenue amounted to $90 \%$ (Antara, 2017).

On the other hand, taxes are income from people's contributions not directly related to the services received by the people. The imposition of funds in the form of tax is binding and mandatory. In fact, the obligation to pay taxes can be imposed by the government. In general, the nature of this tax is what causes people's reluctance to pay. People are 
taxed according to their respective economic capacities, not based on goods or services received by the people. There are no consequences for the people to get services and benefits from the state in accordance with the proportion of funds deposited to the country. As a result of this tax's nature, people demand strict accountability for the taxes they pay. The government must develop a strict accountability mechanism for funds and all resources entrusted by the people.

\section{Business Entities Funding and Ownership}

At its inception, the company obtains funds from investors (i.e., the owner). The fund submission is not a compulsory contribution as applied for tax but submitted by the investors voluntarily to the company by expecting a return on the funds invested. The fund's submission reflects investor ownership of the company. Based on Agency Theory, investors as the principal gives trust to company management as an agent. Then, management of the company management manages the fund.

Once the company is established, the company runs operational activities. For funding its operational sustainability, the company must obtain revenues by selling goods or services to customers (not owners). Sales of goods and services to customers are nonbinding and cannot be forced by the company.

Funding and Ownership Comparison between Public and Business Entities

In the aspect of initial capital formation, both the state and companies have in common. The similarity can be seen from volunteerism's aspect to hand over funds and economic resources to the entity. In the concept of state, it can be identified from the willingness to surrender all economic resources, natural resources, and human resources to the state by people in an area/region who declare themselves to join the country. The size of resources contribution submitted to the formation of the state does not affect the portion of ownership of the state. All people are equal in the eyes of the state, both their rights and obligations. Furthermore, state ownership is a collective that cannot be divided into individual or community groups. Thus, state ownership cannot be traded.

On the company side, the size of the contribution of the resources submitted by the capital owner will affect the ownership portion of the company. The higher the contribution of resources provided, the greater the share of ownership of the company. Besides, ownership of the company can be divided into specific units, such as shares. As a result, ownership of the company can be traded.

The main difference between operational funding between a business entity and a public entity is from whom the primary income comes from. The main source of income for public entities comes from the mandatory contributions of their people (owners) and the use of their natural resources. On the other hand, business entities finance their operations through the sale of goods and services to their customers (not owners). The company cannot force this sale. 


\section{Implications of Two Different Upstream}

The differences in motivation and background of the entity's establishment, the way to achieve the entity's objectives, and entity's funding sources, as explained in the paragraphs above, have implications for many areas. One of the areas is financial management. Implications on financial management aspects include planning, budgeting, implementing, and reporting (i.e., managerial accounting, financial accounting, and financial statement analysis).

\section{Planning and Budgeting}

Planning and Budgeting in Public Entities

As explained in the previous sections, to carry out its programs and activities, the government gets funding from various sources. The primary source of government revenue is tax. Tax revenue is directly related to the people as the owner of the country. Again, it needs to be emphasized that taxes are a mandatory contribution from people to the government that there is no direct relationship between contributions that are surrendered by the people and services obtained by the people. Based on the such characteristics of taxes, the demand arises for transparency and accountability in the way of allocating taxes and how to use taxes. To fulfill these demands, all people must be involved in every use of the state's funds. As a consequence, every allocation and use of funds must have people's approval. Therefore, the structure and mechanism of state finansial management must be designed to ensure people's participation as state owners in managing economic funds and resources; and simultaneously control/supervise the government as the manager of economic resources. These structures and mechanisms are manifested in the form of legislation. As a result, since the planning stage of economic resources use for country development, a series of processes have been carried out to ensure that there is a role for the people as fund owners in determining government spending policies.

In the aspect of long and medium-term development planning, all development planning, for example, the National/Regional Long Term Development Plan and the National/Regional Medium Term Development Plan, must obtain people's approval through the parliament in the form of national regulation (i.e., act) or regional regulations. In aspects of annual budgeting, the General Budget Policy must be agreed together by the government and parliament. Furthermore, the central/local government budget must be approved by the parliament. Thus, the Long/Medium-Term Development Plan and the Revenue and Expenditure Budget are working contracts between the government and the people. People entrust all resources to be managed by the government. This working contract contains a plan to use funds and all public resources to implement programs and activities for the benefit of the people. For the government, this working contract is used as a media of accountability for stewardship that will and has been done. From the people's side, the working contract is used as a control tool to measure and evaluate the government's performance in managing public funds to achieve the objectives of the state, namely to realize welfare for the people. 
Ritonga

Public Accounting and Business Accounting: Two Different Upstream

The realization of the working contract must be reported to people at the end of the fiscal period.

\section{Planning and Budgeting in Business Entities}

Agency Theory states that the owner (principals) enter into a partnership with management (agent) to manage the owners' capital. The capital owners delegates their authority to the agent so that the agent can maximize the company's resources for the benefit of the company, which then has an impact on increasing the owners' net capital.

According to the Chartered Institute of Management Accountants (2005), a budget is a quantitative statement of plans for a certain period, including planning sales volumes and revenues, the number of resources, costs and expenses, assets, debt, and cash flow. The budget states the planning of business units, organizations, activities, and activities in measurable units. The budget is an instrument that contains ways/strategies that will be adopted by company management to maximize profits, not as a tool of accountability. Planning and budgeting governance in the company is preferred for internal purposes in the context of maximizing corporate profits. Thus, the budget is an internal management document that does not need to get owner approval.

Planning and Budgeting Comparison between Public and Business Entities

The participation of business entities owners in planning and budgeting is not as essential and crucial as in public entities. This condition caused by the differences in characteristics (nature) of funding from the entity's owner. The characteristic of funding (i.e., tax) in public entities makes the budget as a working contract between people and the government. Meanwhile, in business entities, budget is not a contract between management and owner. The company budget is internal instruments prepared by management. Other reasons are as follows:

1. Planning and budgeting in the company do not reflect the capital owner's aspirations. Planning and budgeting reflect the strategy used by management in achieving organizational goals. Owner aspirations are more reflected on the targets of each company, for example, profit target. This situation is very different from public entities where planning and budgeting must reflect the aspirations of people. Again, budget in a public entity is a working contract between people and government, whereas, in business entities, the budget is not a working contract between management and owner.

2. Leaking information on the budgeting process and the amount of budget to competitors can cause management strategies to be ineffective and fail. Basically, the strategy is the key to organizational success that must be kept secret from its competitors. In public entities, budgeting information and budget amounts need to be known by all people to create transparency and accountability in managing public funds. Therefore, there is a significant difference between company budget and government budget in the aspect of transparency and accountability. 
Ritonga

Public Accounting and Business Accounting: Two Different Upstream

\section{Financial Accounting and Financial Reporting}

\section{Financial Accounting and Financial Reporting in Public Entities}

To account for working contracts for the implementation of programs and activities contained in the government budget, public entities must prepare reports on the realization of the budget. The budget realization report gives information to the public about executive capabilities in fulfilling the contract to people.

To prepare a report on the implementation of the budget, accounting is needed. Thus, the government needs an accounting system, which presents information that can juxtapose contracts/promises with their realization. This accounting system is called Budgetary Accounting (Mardiasmo, 2009). This system is also known as a budget realization reporting system. In Indonesia, two finansial reports are created from the reporting system for budget realization named Statement of Budget Realization and Statement of Changes of Surplus/Deficit after Budget Financing (Republic of Finansial, 2010). Because the government budget is prepared based-on a cash basis, consequently, budgetary accounting is also implemented based-on a cash basis. Thus, the presentation between contracts/promises and the realization of the contract promise in the Statement of Budget Realization are comparable.

In administering people's mandate, the government does not only use funds/cash budgeted in the government budget but also uses non-cash assets/resources (land, building, equipment, etc.) that are entrusted by people. Besides, in the process of providing goods and services to people, rights, and obligations (such as receivables and liabilities) arises between the government and other parties. These aspects must also be accounted for by the government to people. The Budget Implementation Report is unable to inform these matters because those are non-cash transaction and are not included in the government budget. Then, the need for other reports arises, namely operational reports, report on changes in equity, and balance sheet, and cash flow statement. These reports can only be prepared using an accrual-based accounting system. This system is also known as a finansial reporting system. In Indonesia, the obligation to implement the accrual-based finansial reporting system has been carried out finansial later than the 2015 budget (Republic of Finansial, 2015).

Therefore, government entities run two accounting reporting systems simultaneously, namely the budget implementation and the finansial reporting systems. However, in public entity context, the budget realization reporting system is more important because it is a contract between people and government - rather than a financial reporting system. As additional evidence, there is no provision governing the contract for the operational report, balance sheet, report on changes in equity, as well as cash flow reports between the parliament and government. 
Accounting and Financial Reporting in the Company

As explained in the previous section, the company budget is not a contract between management and company owner. Planning and budgeting in the company act as a management instrument to maximize profits, not as a tool of accountability. The governance of planning and budgeting in the company is prioritized for internal purposes to maximize company profits. Therefore, the budget is considered as internal management document that does not need to be declared in company financial report. Thus, owners of the company do not use budget and its realization as a tool to assess the company's financial performance. As a consequence, business entities do not need a budget implementation reporting system or budgetary accounting.

The company's owners will pay more attention to aspects of financial performance achievement, business development, market expansion, and other things directly related to company profits. Therefore, the reporting system needed is a financial reporting system that produces income statements, changes in equity reports, balance sheets, and cash flow statements.

Accounting and Reporting Comparison between Public Entities and Business Entities

Both government and business entities carry out accounting with a different reporting system. Both entities implement a finansial reporting system that generates an income statement (equivalent to operational report for the public entities), equity changes reports, and cash flow statements. However, because of the differences in function and role of budget in each entity, the government entity must also implement a budget realization reporting system - known as budgetary accounting - while business entities do not implement it. Consequently, accounting techniques between public and business entities are different.

\section{Managerial Accounting}

The different ways in achieving goals between business and public entities also impact on its managerial accounting. It needs to be reminded again that to achieve its goals for shareholders' welfare, the company takes a profit-maximizing as its mission. On the other hand, public entities use ways to maximize service delivery to people to achieve their goals. The two aspects of managerial accounting that would be discussed are investment valuation and performance assessment.

\section{Investment Assessment}

Different ways of achieving goals result in different ways of conducting investment assessments by public and business entities. To assess the feasibility of investment, public entities consider both financial and social aspects (non-financial), while business entities only consider financial aspects. 
For public entities, an investment is feasible if the total investment benefits, both financial and social benefits, higher than investment cost (both financial and social costs). Examples of social aspects that should be considered in the feasibility of public investments are increasing crime level, fluctuating unemployment rates, increasing environmental pollution, etc. These aspects are not considered in the feasibility assessment of business entity investment. Furthermore, discount rates level consideration used by public and business investment analysis is also different. Public entities consider social aspects, while business entities only consider the financial aspect. Public entities use social opportunity cost rates (Jones and Pandleburry, 2000), while business entities use financial opportunity cost as their discount rate.

Therefore, the investment feasibility assessment in business entities employs a designed method to maximize profits, such as Net-Present Value (NPV), Internal Rate of Return (IRR), etc. On the other hand, to analyze their investment feasibility, public entities utilize designed methods to maximize services to people, such as Net Present Benefit (NPB), Cost-Benefit Ratio, which consider entire social benefits and social costs.

\section{Performance Measurement}

Different ways of achieving entity goals also lead to differences in entity performance assessment. It needs to be reminded again that to achieve the goal of maximizing shareholder value, the company uses maximizing profits method. On the other hand, public entities use maximizing services methods to achieve the goal. Therefore, the company's executive performance will be assessed based on the ability to earn profits, while the government leader will be assessed based on the ability to provide services.

It is common knowledge for everyone who studies managerial accounting that the performance of a business organization will be measured by indicators such as the profitability index, return on assets (ROA), return on equity (ROE), etc. These indicators are all referred to as the ability of business entities to generate profits. Of course, these indicators cannot be used as indicators to measure public entities' performance. Ritonga (2014) has proposed indicators to measure public entities' performance, such as total fixed assets per capita, public expenditures per capita, the ratio of fixed assets depreciation expenses to fixed assets maintenance expenditures, etc. These indicators measure the capability of public entities to provide services to the community.

\section{Conclusion}

Fundamental differences between the public organization and business organization have occurred since the beginning of the formation of each organization, namely differences in motives and backgrounds of the formation of the organization, goals of the organization's establishment and how to achieve organizational goals, as well as the source and nature of organizational funding. These differences in the upstream give consequences differences in downstream, which are significant dissimilarities between 
the two accounting organizations on planning and budgeting aspects, financial reporting systems (financial accounting), managerial accounting, and auditing.

Differences that occur since upstream also result in differences in theoretical aspects. Theories used to explain phenomena in public accounting will be different from business accounting. For example, Stewardship Theory is more suitable for explaining phenomena in public accounting, while Agency Theory is more suitable for explaining business accounting phenomena.

The arguments above indicate that public accounting and business accounting originated from two different upstream forming. This significant difference in accounting education implies that the curriculum of accounting education must be reconsidered by separating public accounting curricula and the business accounting curriculum. For example, Introduction to Accounting course, which contents are currently biased to corporate entities, cannot be used as common courses for accounting students. The Introduction to Accounting course for public accounting and business accounting should be separated from the beginning to understand this course. In the public accounting context, students have to understand the budgeting process first, while in the context of business accounting, students do not need to do so. Likewise, other courses, such as managerial accounting courses, financial accounting courses, management control system courses, financial statement analysis courses, and accounting theory courses, must be taught separately for students studying public accounting and business accounting. If public accounting is still only considered as one of the concentrations in the accounting program, then students will have insufficient knowledge and inadequate competence in public accounting.

\section{References}

Antaranews.com. (2008). Porsi Penerimaan Pajak di APBN Baru 70 Persen. Retrieved from: http://www.antaranews.com/print/100731/porsi-penerimaan-pajak-di-apbn-baru-70persen [Accessed 10 February 2019]

Bursa Efek Indonesia (BEI). (2020). Profil Perusahaan Tercatat. Retrieved from https://www.idx.co.id/perusahaan-tercatat/profil-perusahaan-tercatat// [Accessed 14 June 2020]

Carneiro, R. L. (1970). A theory of the origin of the state: Traditional theories of state origins are considered and rejected in favor of a new ecological hypothesis. Science, 169 (3947), 733-738

Chartered Institute of Management Accountants. (2005). CIMA Official Terminology. Elsevier.

Fakultas Ekonomika dan Bisnis Universitas Gadjah Mada (FEB UGM). (2020), Struktur Kurikulum, Retrieved from: https://accounting.feb.ugm.ac.id/studyprograms/undergraduate-program/curriculum/curriculum-structure [Accessed 14 June 2020]

Jones, R., \& Pendlebury, M. (2000). Public Sector Accounting. Pearson Education.

Kementerian Keuangan Republik Indonesia. (2017). Perekonomian Indonesia dan APBN 2017. Retrieved from: https://www.kemenkeu.go.id/apbn2017 [accessed 10 February 2019] 


\section{Ritonga}

Public Accounting and Business Accounting: Two Different Upstream

Kementerian Komunikasi dan Informatika. (2020) Kementerian/Lembaga. Retrieved from: https://indonesia.go.id/kementerian-lembaga [accessed 14 June 2020]

Kementerian Koperasi dan Usaha Kecil Menengah. (2020). Data UMKM, Retrieved from: http://www.depkop.go.id/data-umkm [Accessed 14 June 2020]

Komite Standar Akuntansi Pemerintahan (KSAP). (2008). Pimpro Tak Paham Pembukuan: Kebutuhan Akuntan Sudah Sangat Mendesak Untuk Kelola Keuangan Pemerintah Retrieved from: Http://Www.Ksap.Org/Detilberita38.Php, [accessed 14 June 2020)

Kompas. (2020). Jumlah Kabupaten dan Provinsi di Indonesia. Retrieved from: https://www.kompas.com/skola/read/2020/01/08/150000469/jumlah-kabupatendan-provinsi-di-indonesia?page $=$ all $[$ accessed 14 June 2020]

Mardiasmo. (2009). Akuntansi Sektor Publik. Yogyakarta: Andi Offset.

Ritonga, I.T. (2014). Analysing Service-Level Solvency of Local Governments from Accounting Perspective: A Study of Local Governments in the Province of Yogyakarta Special Territory, Indonesia. International Journal of Governmental Financial Management, 14(2), 19-33.

Republik Indonesia. (2010). Peraturan Pemerintah No 71 Tahun 2010 Tentang Standar Akuntansi Pemerintahan, Lembaran Negara Republik Indonesia Tahun 2010 Nomor 123, Jakarta

Republik Indonesia. (1945). Pembukaan Undang-Undang Dasar 1945.

Republik Indonesia. (2018). Undang-Undang Republik Indonesia Nomor 12 Tahun 2018 Tentang Anggaran Pendapatan dan Belanja Negara Tahun Anggaran 2019, Lembaran Negara Republik Indonesia Tahun 2018 Nomor 223, Jakarta.

Republik Indonesia. (2019a). Undang-Undang Republik Indonesia Nomor 20 Tahun 2019 tentang Anggaran Pendapatan Dan Belanja Negara Tahun Anggaran 2020, Lembaran Negara Republik Indonesia Tahun 2019 Nomor 198, Jakarta

Republik Indonesia, (2019b). Peraturan Menteri Dalam Negeri Nomor 72 Tahun 2019 tentang Perubahan Atas Peraturan Menteri Dalam Negeri Nomor 137 Tahun 2017 Tentang Kode Dan Data Wilayah Administrasi Pemerintahan. Berita Negara Republik Indonesia Tahun 2019 Nomor 1327. Jakarta

Sullivan, A., \& Sheffrin, S. M. (2003). Economics: Principles in Action. Upper Saddle River, New Jersey 07458: Pearson Prentice Hall

Tempo.co. (2008). Lembaga Bantuan Hukum Pajak Indonesia Terbentuk. Retrieved from: https://bisnis.tempo.co/read/122275/lembaga-bantuan-hukum-pajak-indonesiaterbentuk [Accessed 10 February 2019]

Tempo.co. (2015). Untuk Republik, Sultan HB IX Sumbang 6,5 Juta Gulden. Retrieved from: https://nasional.tempo.co/read/692958/untuk-republik-sultan-hb-ix-sumbang65-juta-gulden/full\&view $=$ ok $[$ accessed 10 February 2019] 